\title{
Applying the box plot to the recognition of footwall alteration zones related to VMS deposits in a high-grade metamorphic terrain, South Africa, a lithogeochemical exploration application
}

\author{
H.F.J. Theart ${ }^{\mathrm{a}}$, R. Ghavami-Riabi ${ }^{\mathrm{b}}$, H. Mouri ${ }^{\mathrm{c}}$, P. Gräser ${ }^{\mathrm{d}}$ \\ ${ }^{a}$ SRK Consulting (South Africa) (Pty) (Ltd), PO Box 55291, Northlands 2116, South Africa \\ ${ }^{\mathrm{b}}$ Mining, Oil, and Geophysics Department, Shahrood University of Technology, Bolvar Daneshgah, 7 Tir \\ Square, Shahrood, Iran \\ ${ }^{c}$ Department of Geology, University of Johannesburg, South Africa \\ ${ }^{\mathrm{d}}$ Department of Geology, University of Pretoria, South Africa
}

\begin{abstract}
Alteration zones (more commonly foot wall alteration zones) are related to volcanic-hosted massive sulfide (VMS) deposits and represent unique features that may be targeted during exploration. Of these, the chloritic foot wall alteration pipe is the most extensive and characteristic of VMS deposits. This feature is geochemically identified by a strong relative enrichment in aluminium and magnesium and a coupled depletion in calcium and sodium, giving rise to chloritic rocks in the primary environment of formation. During high grade regional metamorphism such chloritic precursor rock types are replaced by an unusual mineral paragenesis, typically containing magnesium rich cordierite, phlogopite, orthoamphiboles or orthopyroxenes and aluminium rich minerals such as sillimanite and corundum. This suggests that the unusual geochemical features of the alteration zone, retained during the deformation and metamorphism, should be recognisable in lithogeochemical exploration.

The massive sulfide deposit in the eastern part of the metamorphic Namaqua Province, South Africa, at Areachap, Kantienpan and the defunct Prieska $\mathrm{Cu}-\mathrm{Zn}$ Mine are hosted by a MidProterozoic volcano sedimentary succession known as the Areachap Group. These deposits were affected by a complex deformation and metamorphic history and represent examples of upper amphibolite to granulite grade metamorphosed VMS deposits.
\end{abstract}

The application of the known lithogeochemical methods is especially complicated where the geology is not well understood, due to the poor rock exposure of complexly deformed and metamorphosed areas, such as in the eastern part of the Namaqua Province.

The box plot presents a more readily applicable lithogeochemical method to characterize and identify the alteration process, but it was designed for relatively un-metamorphosed environments. It is demonstrated here that the box plot may also be applied to high-grade metamorphic terrains and that the mineral phases used in defining the boxplot in low grade metamorphic environments may be replaced by their equivalents in high grade metamorphic terrains. The compositional trends of the metamorphic minerals themselves may be used in defining the boxplot for high grade metamorphic terrains. These include the transition of: annite 
to phlogopite; grossular to almandine or pyrope, augite to enstatite or clinoenstatite, and hornblende to gedrite or cummingtonite. Close to the ore zone, the relative $\mathrm{Mg}$ content of pyroxene, cordierite and biotite are higher than further away from this zone. It could be demonstrated that the changes in the mineral compositions are gradational when comparing unaffected rocks with progressively more altered wall rocks.

Conclusions based on an application of the isocon method demonstrate that primary footwall alteration zones in the Areachap Group's VMS deposits are characterized by elemental depletion of $\mathrm{Na}_{2} \mathrm{O}, \mathrm{CaO}, \mathrm{Sr}, \mathrm{Ni}, \mathrm{V}$ and $\mathrm{La}$ and enrichment of $\mathrm{MgO}, \mathrm{Fe}_{2} \mathrm{O}_{3 \text { (total) }}, \mathrm{S}, \mathrm{Zn}, \mathrm{SiO}_{2}, \mathrm{Co}$ and $\mathrm{F}$. It is shown that the whole rock compositions of rocks that were independently identified as the metamorphic equivalents of altered rocks, using the isocon method, plot in the correct place in the box plot for high grade regionally metamorphosed terrains. This establishes the box plot as an effective and practical tool for lithogeochemical exploration for VMS deposits in complexly deformed high grade metamorphosed terrains.

Keywords : Lithogeochemical exploration; Metamorphic VMS deposits; Footwall alteration zones; Box plot; Isocon method

\section{Introduction}

Footwall alteration zones of volcanic-hosted massive sulfide (VMS) deposits have characteristic mineralogical and lithogeochemical features with footprints much larger than the deposit itself and therefore present excellent exploration targets. During the past three decades, various lithogeochemical techniques have been proposed that could be used to characterize the footwall alteration zones ( Gresens, 1967 ; Grant, 1986) and the associated mass changes especially in metamorphosed systems such as at Snow Lake (Zaleski et al., 1991 ; Galley et al., 1993), Montauban ( Bernier et al., 1987 ; Bernier and MacLean, 1993) and Kristenberg (Barrett et al., 2005). In addition to these studies the usefulness of geochemical indices have been demonstrated and these include the well known Alteration Index (AI) of Ishikawa et al. (1976) defined as: $\left(100\left(\mathrm{~K}_{2} \mathrm{O}+\mathrm{MgO}\right) /\left(\mathrm{K}_{2} \mathrm{O}+\mathrm{MgO}+\mathrm{Na}_{2} \mathrm{O}+\mathrm{CaO}\right)\right)$, to measure the intensity of sericitic and chloritic alteration in the footwall of VMS deposits of the Kuroko type in Japan. One of the more easily applicable methods to quantify the degree of alteration is proposed by Grant (1986) to graphically solve the Gresen's equations. This graphic solution is known as the isocon method. It allows for the quantified expression of the change in concentration of an element in an altered rock, relative to the concentration of the original rock.

Large et al. (2001) combined the AI of Ishikawa et al. (1976) with a chlorite-carbonate-pyrite index (CCPI), defined as: $\left(100\left(\mathrm{MgO}+\mathrm{FeO}_{\text {total }}\right) /\left(\mathrm{MgO}+\mathrm{FeO}_{\text {total }}+\mathrm{Na}_{2} \mathrm{O}+\mathrm{K}_{2} \mathrm{O}\right)\right)$, in a diagram called the box plot. The fields in this diagram are defined by mineral reactions that characterize both hydrothermal alteration in the primary ore-forming physical and chemical environment, and subsequent diagenesis. It should be noted that the methods proposed by Ishikawa et al. (1976) and Large et al. (2001) were designed for areas where the primary minerals involved in the original reactions were largely preserved, and not for areas that were affected by intense deformation and high-grade metamorphism subsequent to sulfide mineralization. 


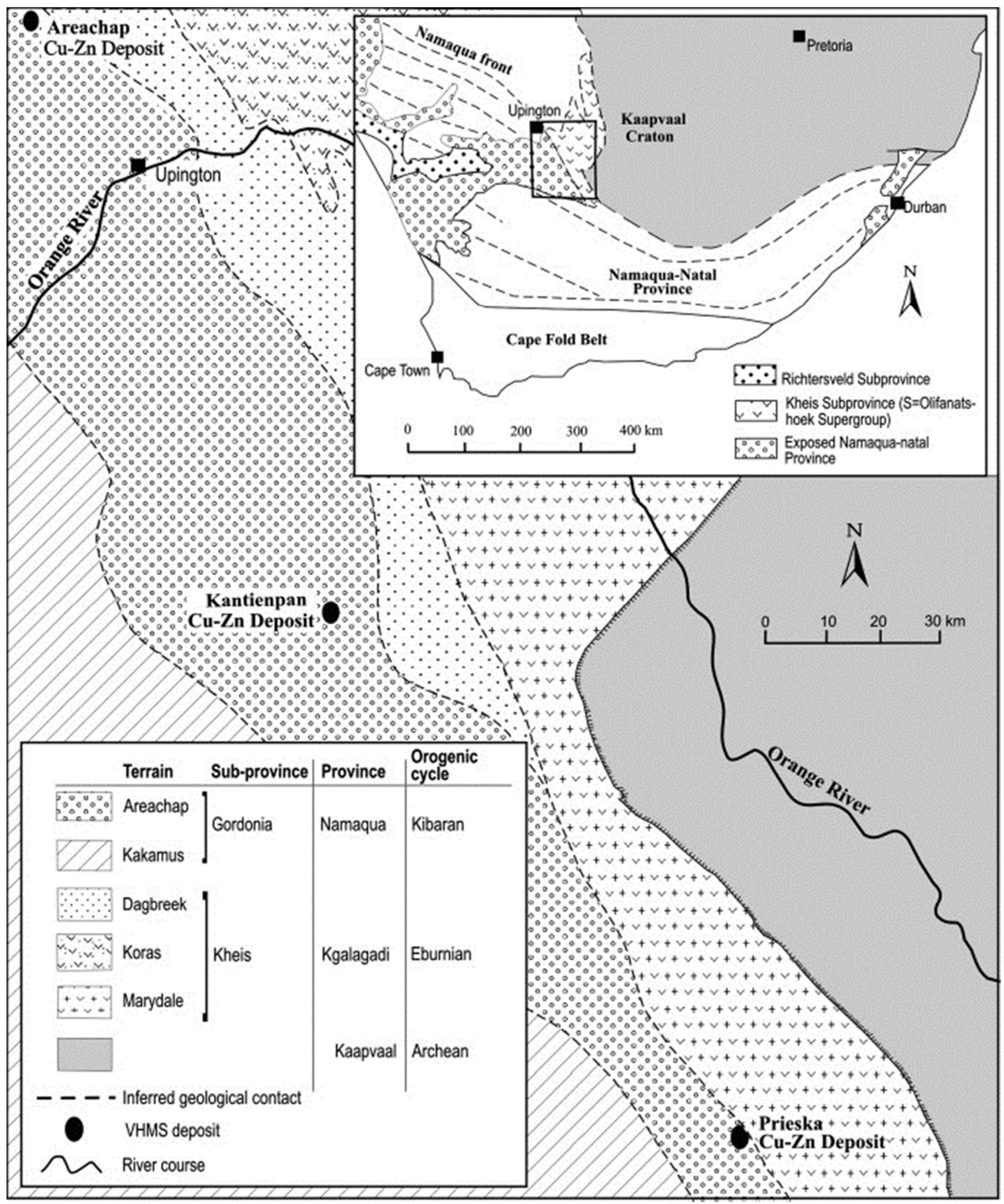

Fig. 1. Map showing the eastern part of the Namaqua Sub-province and the location of the larger volcanic hosted massive sulfide deposits in this area.

The combination of high grade regional metamorphism and deformation, coupled with the intrusion of various types of igneous rocks at different stages throughout the tectonic evolution and the very poorly exposed nature of the eastern part of the Namaqua Province (Fig. 1), makes it very difficult to identify features related to the primary environment within which the ore deposits formed. As a consequence, quantifying the effects of hydrothermal alteration is 
complicated. The objective of this paper is to illustrate the applicability of the box plot in lithogeochemical exploration for VMS type deposits, in such high grade metamorphic terrains.

Previous regional geological and lithogeochemical investigations of the rocks related to massive sulfide ore bodies in the Areachap Group of the eastern part of the Namaqua Province in South Africa were reported by Middleton (1976), Geringer et al. (1986), Theart et al. (1989), Schade et al. (1989), Geringer and Ludick, 1990, Moore et al. (1990), Cornell et al., (1990b, 1992), Humphreys (1993), Geriner et al. (1994) and Thomas et al. (1994). Investigations demonstrated that the protolith to the metamorphic host rocks was a volcano-sedimentary succession and that the cordierite anthophyllite cummingtonite bearing rocks associated with the Prieska $\mathrm{Cu}-\mathrm{Zn}$ Mine represent a metamorphosed hydrothermal footwall alteration zone (Theart et al., 1989). Hence a volcanic hosted massive sulfide (VMS) model was proposed for the genesis of this deposit. Similar conclusions were reached by Gorton (1981) with regard the Kielder sulfide bodies in the same region.

The nature of primary footwall alteration zones related to two other VMS deposits in this region, located in the northern part of the Areachap Group (Fig. 1) is considered here. These deposits occur in a region with almost no rock outcrop. As with the Prieska $\mathrm{Cu}-\mathrm{Zn}$ deposit, the deposits are also affected by complex deformation and upper amphibolite to granulite grade metamorphism. The deposits are known as the Areachap and the Kantienpan deposits. Whereas the Areachap deposit, located $20 \mathrm{~km}$ northwest of the town Upington, was the first massive sulfide deposit to be discovered and mined in this region (Theart, 1985) and the unexploited Kantienpan deposit, approximately $70 \mathrm{~km}$ southeast of Upington, is a relatively new discovery (Rossouw, 2003 ; Ghavami-Riabi et al., 2008). The metamorphic rocks and their protoliths associated with the massive sufides are well described and discussed by these authors.

This paper does not intend to give a comprehensive geological and geochemical overview of one or more of the VMS ore bodies in the Areachap Group, but intends to demonstrate the applicability of lithogeochemical methods and especially the box plot for future exploration in such areas.

\section{Regional geology}

The Kibaran Supercrustal Sequence was deposited on the Eburnian basement in the western Namaqua Terrane (Thomas et al., 1994). The lithology of this sequence may indicate that there was an oceanic basin between the Kaapvaal and the older parts of the Namaqua Province (Theart, 1985) (Fig. 1). The oceanic basin was affected by calc-alkaline and tholeiite volcanism (Cornell et al., 1990a) in the area now preserved in the east-central Namaqua-Natal Province. These extrusive rocks and associated sediments were preserved in the Areachap Group of the eastern part of the Namaqua Province and in the Mfongosi Group of Natal Province (Thomas et al., 1994). During the period of volcanism, volcanogenic massive sulfide deposit formed on the sea floor due to reactions between the hydrothermal fluids and seawater (Cornell et al., 1990a). This was followed by plate convergence, thrusting, ductile transcurrent shearing, thickening of the crustal sequence, and intensive deformation due to a northwest-southeast-directed stress regime (Thomas et al., 1994). The Koras and Sinclair Groups consisting of calc-alkaline volcanic and sedimentary rocks were formed during the late syn-collision event. The collision of cratons 
and the related events led to high-grade metamorphism and widespread melting and generation of voluminous granitiod batholiths magma (I-type granites) (Geringer et al., 1994).

The poorly exposed Areachap Group that hosts VMS style base metal deposits is preserved in a tectonic terrain along the eastern margin of the Namaqua Metamorphic Province (Fig. 1). Its age ranges from approximately $1200 \mathrm{Ma}$ to $1600 \mathrm{Ma}$ (Barton and Burger, $1983(\mathrm{~Pb}-\mathrm{Pb})$; Theart et al., $1989(\mathrm{~Pb}-\mathrm{Pb})$; Cornell et al., $1992(\mathrm{Rb}-\mathrm{Sr}, \mathrm{Sm}-\mathrm{Nd}))$, but isotopic age determinations are hampered by the complex tectonic history of the area and the resetting of the isotope systems by both contact and regional metamorphism. Cornell and Pettrsson reported an age of $1285 \pm 14 \mathrm{Ma}$ for the matadacite in the Copperton Formation, and $1275 \pm 7 \mathrm{Ma}$ for metasediments in the Boksputs Formation of the Areachap Group.

The Areachap Group was affected by deformation and metamorphism related to the accretion of various tectonic terrains within the Namaqua Province and its accretion to the Kaapvaal Craton ( Stowe, 1983 ; Theart, 1985 ; Hartnady et al., 1985 ; Moen, 1988 ; Theart et al., 1989 ; Moore et al., 1990 ; Cornell et al., 1992 ; Thomas et al., 1994). Cornell et al. (1992) proposed an empirical pressure-temperature-time $(P-T-t)$ path explaining the metamorphic evolution of the Areachap Group rocks at the Prieska $\mathrm{Cu}-\mathrm{Zn}$ mine. The supracrustal sequence was affected by an early collision event which led to a rapid increase in pressure during thrust-dominated, deep level deformation, resulting in early isoclinal to shear folding (F1 and F2), and mineral parageneses reflecting upper amphibolite to granulite grade $\left(\mathrm{M}_{1}\right)$ metamorphic conditions (Theart, 1985 ; Humphreys et al., 1988).

Thermal relaxation, caused by the widespread intrusion of syntectonic granitic melts, resulted in the formation of the pervasive high temperature, high pressure metamorphism $\left(\mathrm{M}_{2}\right)($ Cornell et al., 1992). This largely replaced earlier metamorphic assemblages (Theart, 1985 ; Theart et al., 1989) giving rise to the predominant high-grade upper amphibolite grade metamorphic mineral assemblages.

Later, uplift and erosion led to a gradual decrease in pressure at an almost constant temperature (Cornell et al., 1992). Earlier isoclinal folds had predominantly sub-horizontal axial cleavage foliation planes, the subsequent deformation resulted in a series of phases of folding where the axial planes are sub-vertical and the folds themselves formed through a process of buckle folding (F3 and F4) (Theart, 1985). This deformation probably took place at higher tectonic levels during the assembly of the different terrains of the Kibaran Namaqua-Natal Province.

This was followed by the development of grain boundary textures $\left(\mathrm{M}_{3}\right)$ indicative of a hydrous fluid influx at high temperatures and a slightly lower pressure, seen in the replacement of $\mathrm{M}_{1}$ cordierite along grain boundaries by sillimanite, phlogophite and almandine (Cornell et al., 1992). Theart (1985) describes similar textural features in the other rocks throughout the Areachap Terrain and it is concluded that these features are related to the widespread intrusion of the late (1100 Ma) tectonic granites of the Vaalputs or Keimoes Suites. The intrusions of these granites are interpreted to be a stitching event following the accretion of the Kakamas and Areachap Terrains. 
Following the intrusion of these batholiths, a steady state geotherm was re-established (Cornell et al., 1992). Shear zones within the eastern part of the Namaqua Province recorded northward shortening in excess of $400 \mathrm{~km}$ (Stowe, 1983) and reflect retrograde metamorphism $\left(\mathrm{M}_{4}\right)$ caused by ascending hydrothermal fluids (Theart et al., 1989). Cornell et al. (1992) suggested that the final accretion with the Kaapvaal Craton took place some $965 \mathrm{Ma}$ ago and that the rocks, currently exposed at surface, were first exposed some $550 \mathrm{Ma}$ ago before it was again covered by the largely now eroded 300-180 Ma sedimentary rocks of the Karoo Supergroup (Catuneanu et al., 2005).

\section{Local geological setting}

The massive sulfide deposits at Kantienpan, the defunct Prieska $\mathrm{Cu}-\mathrm{Zn}$ Mine at Copperton, and the old Areachap Mine, are all situated within the Areachap Terrain of the Gordonia Subprovince of the metamorphic Namaqua Province (Fig. 1) ( Geringer et al., 1986 ; Theart et al., 1989 ; Cornell et al., 1990b ; Rossouw, 2003). Supracrustal rocks in Gordonia Subprovince belong to the Areachap Group consisting of the Jannelsepan, Boksputs and Copperton Formations (Barton and Burger, 1983 ; Cornell et al., 1990b; Rossouw, 2003).

The Copperton Formation comprises six members, of which the Smouspan Member, a hornblende-biotite gneiss, underlies the Prieska Copper Mines Member (PCMM), hosting the massive sulfide ore body at Copperton (in an overturned succession). The PCMM consists of a variety of peraluminous gneisses, including tourmaline-phlogopite-albite-gedrite gneiss, and a phlogopite-sillimanite-perthite-cordierite-quartz gneiss representing the metamorphosed footwall alteration zone of the Prieska deposit, and a phlogopite-sillimanite-perthite-cordierite quartz gneiss representing the hanging wall alteration zone (Theart, 1985).

The Boksputs Formation hosts the Kantienpan deposit (Fig. 2) and consists of three members (Geringer et al., 1994 ; Rossouw, 2003) : (i) quartz-feldspar gneiss; (ii) garniteferous gneiss; quartzite and calc-silicate gneiss and (iii) hornblende gneiss. The ore zone is hosted by the second member, consisting of peraluminous and calcsilicate gneisses, where a sillimanitecordierite gneiss forms the metamorphosed footwall alteration zone of the massive sulfide zone, and banded hornblende gneiss, representing hanging wall metasedimentary rocks (GhavamiRiabi, 2007).

The Jannelsepan Formation that hosts the Areachap deposit (Fig. 3) comprises four members ( Theart, 1985 ; Voet and King, 1986 ; Theart et al., 1989 ; Cornell et al., 1990b ; Geringer et al., 1994) : (i) quartzo-feldspathic gneiss; (ii) hornblende-biotite gneiss, biotite-hornblende gneiss and massive amphibolites; (iii) banded biotite gneiss; and (iv) porphyroblastic diopside bearing amphibolite with intercalated calc-silicate rocks. The ore zone is hosted in the second member, and consists of a footwall alteration zone represented by garnet-sillimanite cordierite gneiss, and the hanging wall rocks formed by hornblende gneisses ( Theart, 1985 ; Ghavami-Riabi, 2007).

Middleton (1976), Gorton (1981), Theart (1985) and Cornell et al. (1990b) inferred that the hornblende gneiss, known as the Smouspan Member of the Copperton Formation, had a dacite as 


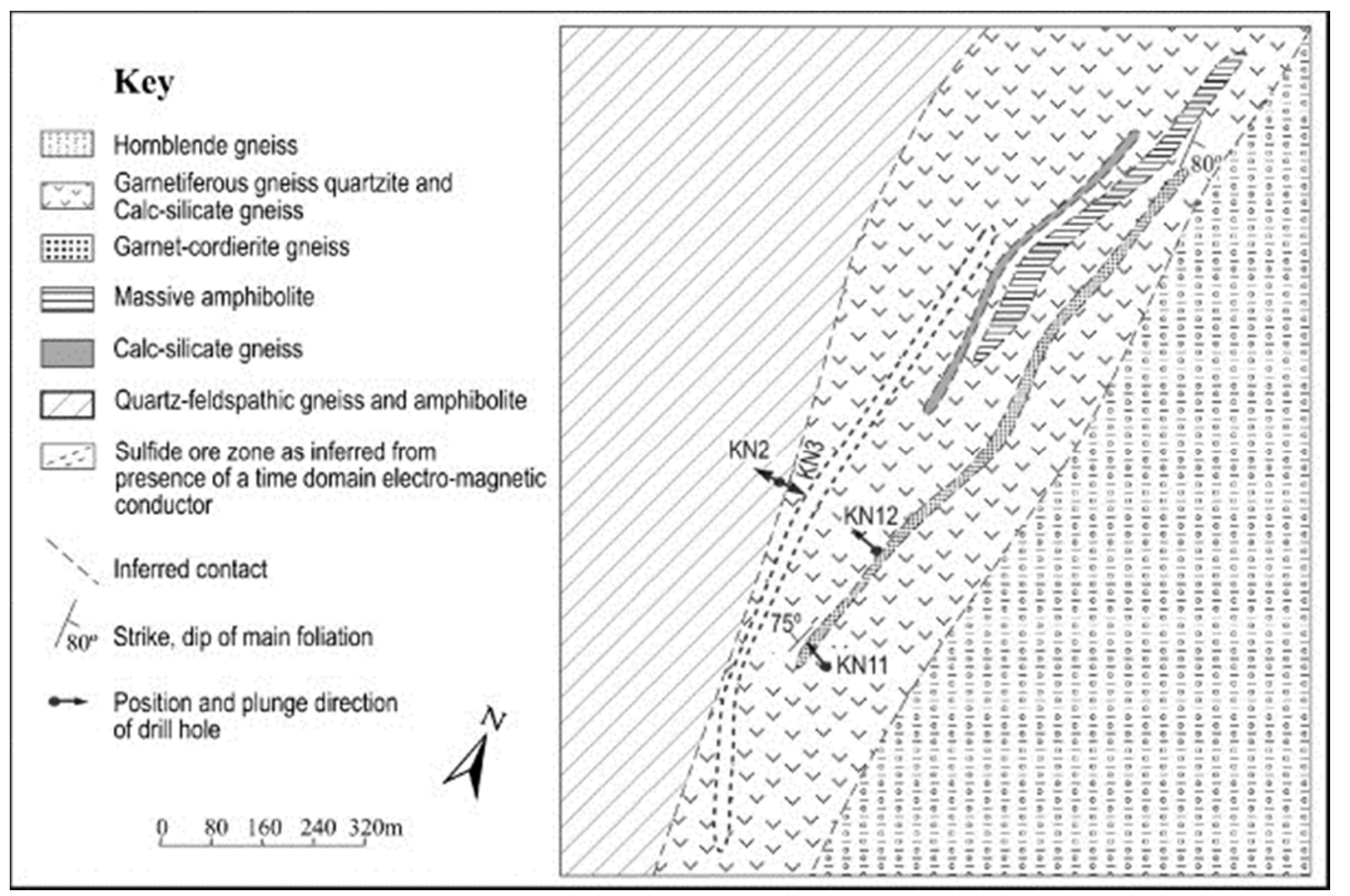

Fig. 2. Inferred geological map of the local geology at the Kantienpan deposit showing the collar positions of the drill holes referred to in the text (after Rossouw, 2003).

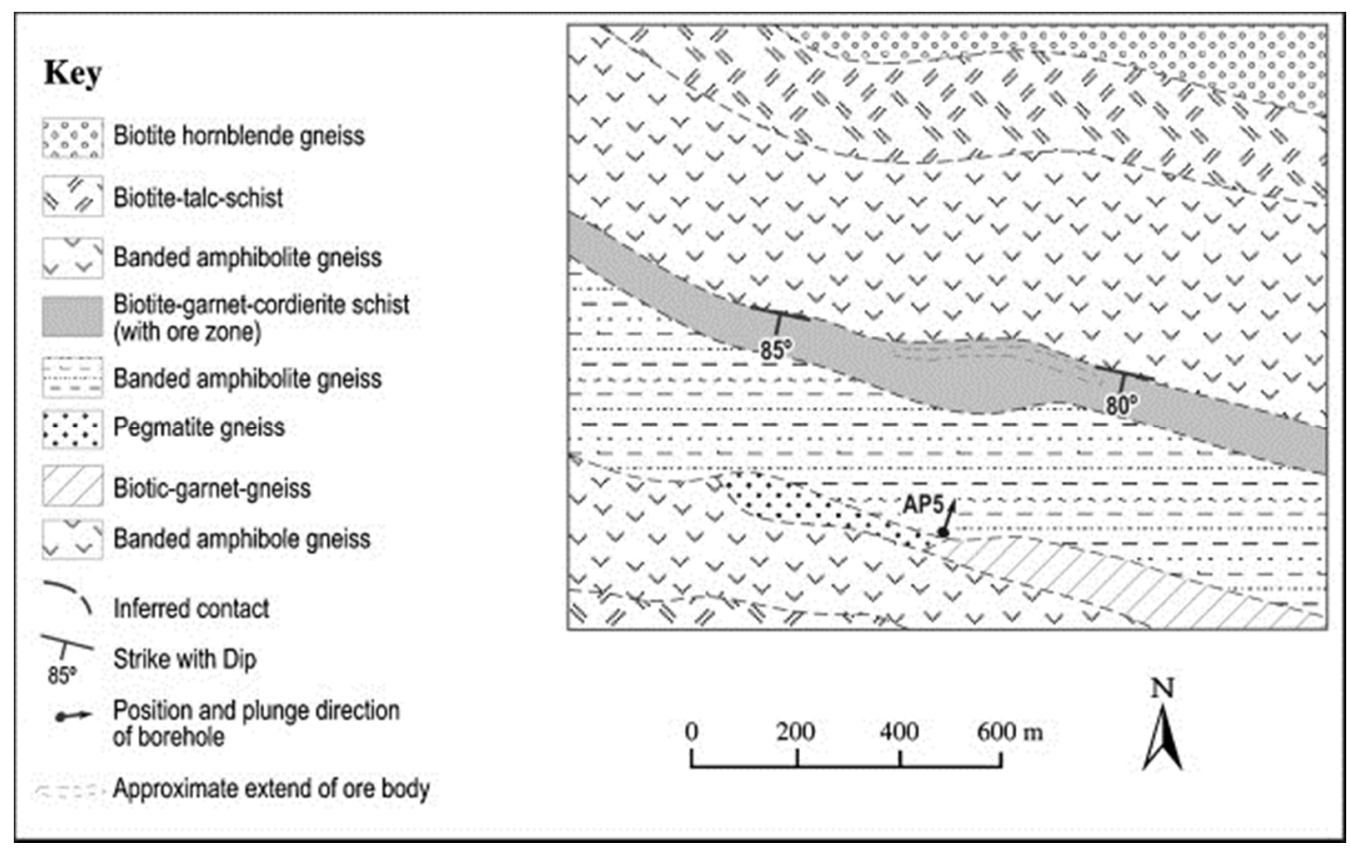

Fig. 3. Inferred geological map of the local geology at the Areachap deposit showing the collar position of the drill hole referred to in the text (after Voet and King, 1986).

precursor, based on general lithological features, major and trace element geochemistry, isotope systematics (Theart et al., 1989), and the zircon crystal morphology (Pupin, 1980). The hornblende-biotite and biotite-hornblende gneiss of the Jannelsepan (AR5) and Boksputs 
Formations probably had a similar precursor (Theart, 1985 ; Rossouw, 2003). Theart (1985) and Ghavami-Riabi (2007) regarded the massive amphibolite layers in these successions as metamorphosed and deformed dolerite sills and dykes that intruded the successions after the primary alteration related to the ore forming process. The laminated amphibolite of the Copperton Formation and porphyroblastic diopside bearing amphibolite with intercalated calcsilicate bands from the Boksputs and Jannelsepan Formations had MORB type (flat rare earth profiles and primitive isotopic signatures) and calcareous ocean floor sediments as precursors (Theart, 1985).

Middleton (1976) and Geringer et al. (1994) suggested that the Copperton, Boksputs and Jannelsepan Formations are time equivalents that formed at separate volcanic centres. An alternative interpretation is the three formations are separated tectonically and by granitic intrusions.

\section{The VMS deposits}

The metamorphosed stratiform massive sulfide deposits of the Namaqua Province may be divided into the sediment hosted, massive sulfide Aggeneys Group ( Ryan et al., 1986 ; Thomas et al., 1994) and the VMS Copperton Group (Theart et al., 1989), based on lithological, compositional and isotopic characteristics. The Aggeneys Group includes the Broken Hill, Big Syncline, Black Mountain and Gamsberg deposits, whereas the Copperton Group include the Prieska $\mathrm{Cu}-\mathrm{Zn}$ deposit (47 Mt at 1.7\% Cu and 3.8\% Zn, mined out) (Theart et al., 1989 ; [Schade et al., 1989), the Kantienpan deposit (5 Mt at 0.49\% Cu and 4.09\% Zn) (Rossouw, 2003), and the Areachap deposit (8.9 Mt at $0.40 \% \mathrm{Cu}$ and 2.24\% Zn) (Theart, 1985 ; Voet and King, 1986) and various smaller deposits and occurrences not listed here. The Copperton Group of deposits is confined to the Areachap Terrain.

The ore body at Areachap consists of discontinuous massive sulfide lenses (Voet and King, 1986) ranging in thickness from 0.1 to $24.2 \mathrm{~m}$. The Kantienpan deposit consists of stratiform $\mathrm{Zn}-$ $\mathrm{Cu}$ bearing massive sulfide lenses (Rossouw, 2003). Disseminated sulfide minerals described (listed in the relative order of abundance) in the footwall of these deposits include chalcopyrite, pyrite, and sphalerite at Areachap, pyrrhotite, chalcopyrite, and pyrite at Kantienpan, and pyrrhotite, chalcopyrite, pyrite, and sphalerite at the Prieska $\mathrm{Cu}-\mathrm{Zn}$ deposit. The massive ore zones comprise pyrite, sphalerite, phyrrhotite, chalcopyrite, barite, anhydrite, and trace amounts of galena. Disseminated magnetite, pyrite and sphalerite are present in the hanging wall successions. No primary textures survived in the massive sulfides and silicate rocks of these deposits and they display classic durchbewegung textures reflecting the deformation and recrystallization due to metamorphism (Theart et al., 1989).

\section{Analytical methods}

A total of 160 rock samples, 73 samples from Areachap (27 samples from drill hole AP2 (this borehole was drilled in the pegmatite gneiss unit, in the NW and about $300 \mathrm{~m}$ of borehole AP5), and 46 samples from drill hole AP5) (Fig. 3), and 87 samples from Kantienpan (49 samples from drill hole KN11, 38 samples from drill hole KN12 and five samples from outcrop) (Fig. 2), were collected and analysed for mineral and whole rock chemistry. A CAMECA EPMA-SX 100 
Electron Microprobe at the University of Pretoria, was operated at $20 \mathrm{kV}$ accelerating voltage, $20 \mathrm{nA}$ beam current and the samples were analysed using a focused beam. K $\alpha$ was used for all elements. Only the cores of individual mineral grains were analysed, where no secondary alteration features could be observed.

The whole rock major and trace element compositions were determined with an ARL 9400XP + Wavelength dispersive X-ray Fluorescence Spectrometer (XRF) at the Geology Department, University of Pretoria. Major element analyses were executed on fused beads, following the standard method as adapted from Bennett and Oliver (1992). Trace elements were analysed using pressed powder pellets, applying an adaptation of the method of Watson (1996). The XRF Spectrometer was calibrated with certified reference materials. Accuracy and precision was monitored through the repeated analyses of in-house and international standards and duplicate samples. The lower limit of detection for the trace elements analysed was equal to, or less than $3 \mathrm{ppm}$ with the exception of $\mathrm{Zn}(4 \mathrm{ppm}), \mathrm{Zr}(10 \mathrm{ppm})$ and $\mathrm{W}(6 \mathrm{ppm})$. The standard deviations based on the repeated analyses are very similar to the limit of detection of the respective elements.

The NBSGSC fundamental parameter program was used for matrix correction of major elements as well as for $\mathrm{Cl}, \mathrm{Co}, \mathrm{Cr}, \mathrm{V}, \mathrm{Sc}$ and $\mathrm{S}$, and the Rh Compton peak ratio method was used for the other trace elements. Sulfide samples were analysed as pressed powder briquettes and processed using the UNIQUANT software, a fundamental parameter based programme, calibrated with pure metals and oxides. Results for $\mathrm{Cl}$, and $\mathrm{S}$ are indicated as semi-quantitative, as the standard deviations achieved on the reference materials are large $(\mathrm{Cl}=117 \mathrm{ppm}$, and $S=300 \mathrm{ppm})$. However, in terms of the observed concentrations of these elements in most of the samples analysed, the limits of detection for these elements are acceptable $(\mathrm{Cl}=8 \mathrm{ppm}, F=100 \mathrm{ppm}$ and $S=16 \mathrm{ppm})$.

The results of these analyses are listed in Tables A1 and A4.

\section{Mineral chemistry near the ore zones}

Selected microprobe analyses of samples from the rock successions adjacent to the ore bodies at Areachap and Kantienpan are given in Tables A5-A10. At Areachap, the ore is hosted by biotitegneiss, biotite-hornblende-gneiss and biotite garnet schist (Fig. 3). The rocks, containing cordierite, sillimanite, garnet and biotite, structurally overlying the ore zone are interpreted to represent the primary footwall (Ghavami-Riabi, 2007). Gneissic rocks structurally below the ore zone, interpreted to be the primary hangingwall (Ghavami-Riabi, 2007), contain more hornblende and biotite.

The ore zone at Kantienpan is overlain by biotite-gneiss and biotite-hornblende-gneiss within the amphibolite and finely banded gneiss and quartzite unit (Fig. 2). In contrast, the gneiss below the ore zone contains cordierite, sillimanite and biotite, reflecting its peraluminous, calcium-poor character (Ghavami-Riabi, 2007). Gneissic rocks intercalated with the massive sulfide (towards the upper contact of the ore zone) contain hornblende and biotite, indicating a progressively more calcareous composition. In general, the variation in the plagioclase composition at the Kantienpan deposit given in Table A5 and shown in Fig. 4, does not reflect the changes in the 
bulk rock composition (Table A4). The higher anorthite content in plagioclase in sample KN11/40 of $77.56 \%$ contradicts the fact that this sample comes from a calcium depleted zone (Table A4). This indicates that plagioclase is the only mineral phase in these rocks that hosts the little available $\mathrm{Ca}$ in the system. The rock itself consists of 50-55\% quartz, 20-25\% orthopyroxene, $7-10 \%$ cordierite, $5-7 \%$ biotite, and minor amounts of sillimanite, plagioclase, $\mathrm{K}$-feldspar, pyrite, magnetite, and zircon. Plagioclase in a sample from a massive amphibolite layer above the ore zone (KN11/32) with an anorthite component of $55.21 \%$ and a K-feldspar component of $0.69 \%$, confirms the interpretation that the protolith of these rocks represent basaltic dykes or sills that intruded the succession prior to deformation and metamorphism. At Areachap the variation in the composition of plagioclase could be correlated with the variation in the bulk rock composition. The anorthite component in plagioclase from the zone of calcium depletion ranges from 0.53 to $12.78 \%$ compared to $21.26 \%$ in the calcium enriched zone. Highly variable anorthite contents in plagioclase ranging from 0.47 to $24.09 \%$ may also be seen to reflect a variable $\mathrm{Ca}$ content in the ore zone (Tables A2 and A5).

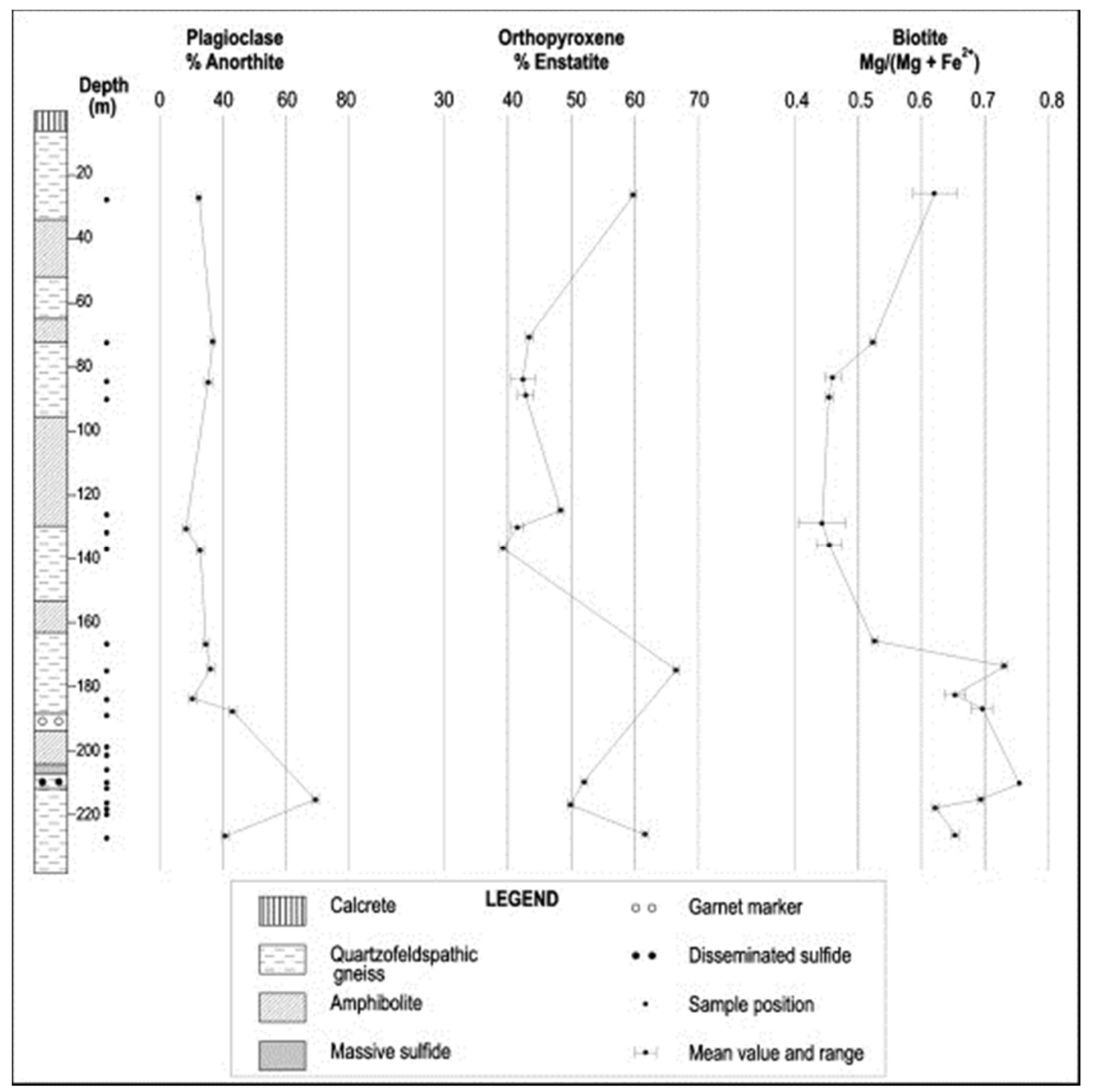

Fig. 4. Compositional variation of plagioclase, orthopyroxene and biotite in drill hole KN11 at Kantienpan.

Magnesium enrichment of the footwall alteration zone is demonstrated by the variation in the composition of pyroxene (Fig. 4), where the enstatite end member's abundance is generally lower in the hanging wall $(<45 \%)$ than in the footwall rocks $(\geq 50 \%)$. An exception to this is the relatively high enstatite content of $66.68 \%$ in pyroxene from sample KN11/27 in the hanging 
wall succession at Kantienpan. Pyroxene, analysed from the original footwall zone at Areachap also contains more than $50 \%$ of the enstatite end-member (AP5/38 with 55.64\% enstatite, Table A6).

The magnesium number $(\mathrm{Mg} \#=100 \mathrm{Mg} /(\mathrm{Mg}+\mathrm{Fe}+\mathrm{Mn}))$ of cordierites in both footwall and hangingwall rock types at Kantienpan is generally high $(>70)$, with cordierite in the hanging wall as high as 91.37 (KN11/25). Cordierite from the footwall succession at Areachap has Mg\# in excess of 70 as well (samples AP5/28, AP5/29 and AP5/32, Table A7).

Garnet in the footwall alteration zone and the ore zone at Areachap has elevated almandine and pyrope contents with low spessartine and grossular components (Table A8). The garnets in the ore zone (samples AP5/42 and AP5/43) have high grossular contents and low almandine contents (Table A8). The spessartine content of $48.27 \%$ in garnets from the ore zone at Kantienpan (sample KN11/34) is exceptionally high (Table A8).

The variation in the $\mathrm{Mg} /\left(\mathrm{Mg}+\mathrm{Fe}^{2+}\right)$ ratio of biotite in the host rocks of the Areachap and Kantienpan deposits is given in Table A9 and illustrated for the Kantienpan deposit in Fig. 4. Phlogopite is more common adjacent to the ore zones in the footwall alteration zones in both drill holes. The biotite in sample AP5/35, is more Fe-rich $\left(6.28 \%\right.$ of $\left.\mathrm{Fe}_{2} \mathrm{O}_{3}\right)$ and may be referred to as annite. The mica in this sample reflects the bulk rock composition of areas immediately below the ore zone that probably escaped the alteration processes, as its precursors were probably some distance away from the primary feeder zone.

The presence of spinel in these rocks close to the ore zone at Kantienpan confirms the peraluminous characteristic of the footwall alteration zone and ore zone and it is regarded as an indicator mineral of the hydrothermal alteration that affected the precursor rocks. Spinel from the ore zone and in the footwall alteration zone has a high $\mathrm{Zn}$ content (samples KN11/34, KN11/42 and $\mathrm{KN11/43)}$ indicating that it is of the gahnite type (Table A10).

\section{High-grade metamorphic minerals and the box plot}

To understand the bulk mineral processes responsible for the whole rock compositions at VMS deposits, Large et al. (2001) proposed the box plot that attempts to discriminate whole rock geochemical changes, based on the primary mineral reactions that characterize ore forming hydrothermal processes from those related to common rock forming events and weathering. The challenge now is to identify the nature and composition of the metamorphic equivalents of these minerals and to demonstrate the applicability of the box plot in dealing with the compositions of high-grade metamorphic rocks. Upper amphibolite to granulite-grade silicate wall rocks from the Kantienpan and Areachap massive sulfide deposits is assumed to represent the isochemically metamorphosed products of rocks, affected by hydrothermal alteration during the formation of the ore bodies. The composition of metamorphic minerals and the whole rock compositions are used here to demonstrate the applicability of the box plot and to highlight its potential use during exploration in high-grade metamorphic terrains.

The location of the rock forming metamorphic minerals in the box plot may be used to relate them to the specific processes, or to the typical mineralogical reaction trends in the precursor 
rocks as identified by Large et al. (2001). Mineral compositions are used to calculate both the AI and CCPI values and these are plotted in the box plot (Fig. 5 and Fig. 6).
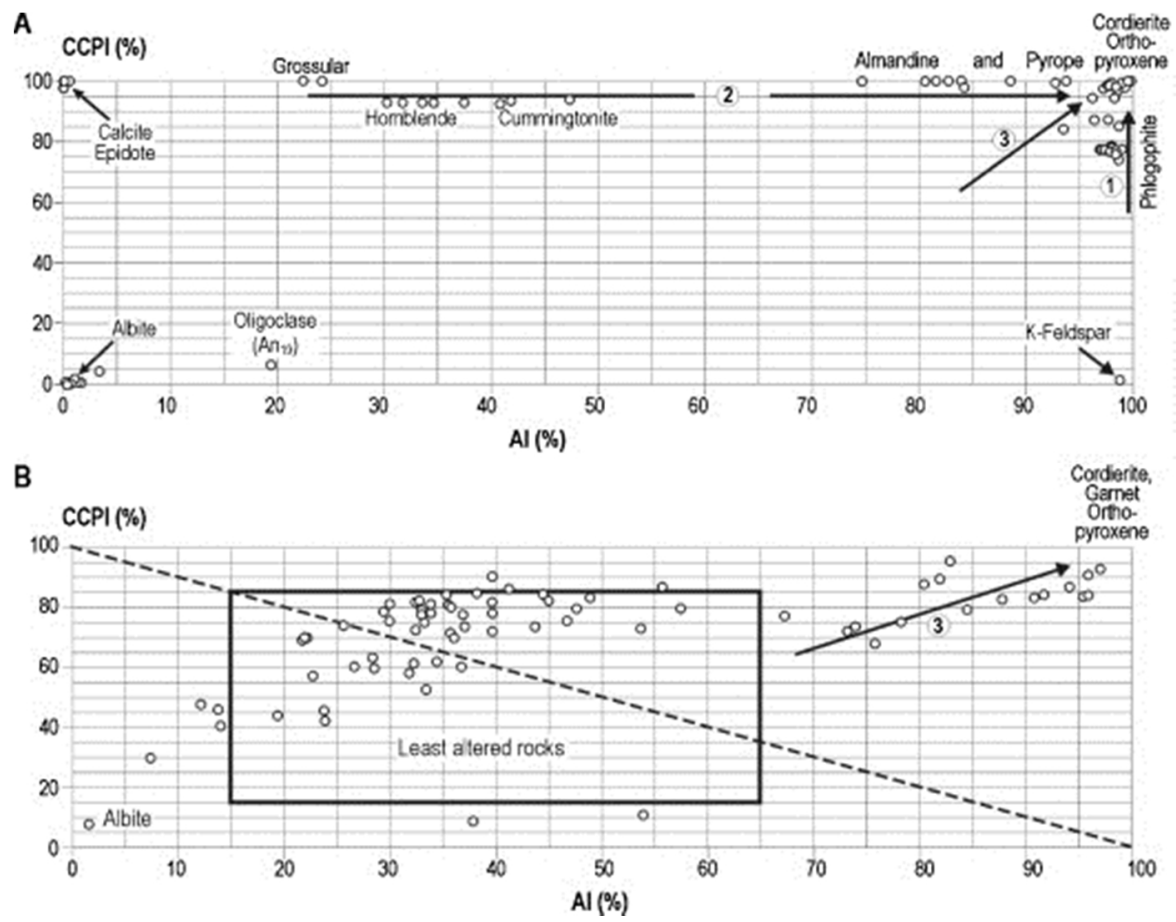

Fig. 5. Box plot diagrams of CCPI against AI for minerals (A) and whole rock compositions (B) from Areachap, where $\mathrm{CCPI}=(\mathrm{MgO}+\mathrm{FeO}) /\left(\mathrm{MgO}+\mathrm{FeO}+\mathrm{Na}_{2} \mathrm{O}+\mathrm{K}_{2} \mathrm{O}\right) \times 100$ and $\mathrm{AI}=\left(\mathrm{K}_{2} \mathrm{O}+\mathrm{MgO}\right) /\left(\mathrm{K}_{2} \mathrm{O}+\mathrm{MgO}+\mathrm{Na}_{2} \mathrm{O}+\mathrm{CaO}\right) \times 100$. The mineral composition trends shown as numbers 1,2 and 3 in these figures, are discussed in the text. The least altered box as defined by Large et al. (2001) is shown in (B).

Three mineralogical compositional trends may be identified in the box plot for high-grade metamorphic rocks:

(1) The first trend corresponds to the variation of annite to phlogopite in the micas and these minerals plot on the right hand side of the box plot (Fig. 5 and Fig. 6) where the AI values are greater than 95 .

(2) The second trend shows the variation in the composition of pyroxene, amphibole and garnet. These minerals plot at the top of the diagram (CCPI values >90), with Mg-rich cordierite plotting in the top right corner. Compositional variations observed here includes: (i) augite to enstatite and clinoenstatite, (ii) hornblende to cummingtonite and gedrite, (iii) grossular-rich garnet to almandine/pyrope-rich garnet, and (iv) Fe-rich cordierite to Mg-rich cordierite.

(3) The third trend is a diagonal, whole rock compositional trend confined to the upper right hand quarter of the box plot, where the compositions of assumed hydrothermally altered rocks display AI and CCPI values greater than 70. Here rocks that are composed of mixtures of the minerals identified on the periphery of the box plot, define the same trend as the trend identified 
by Large et al. (2001) for rocks affected by hydrothermal alteration at the time of massive sulfide mineralization.

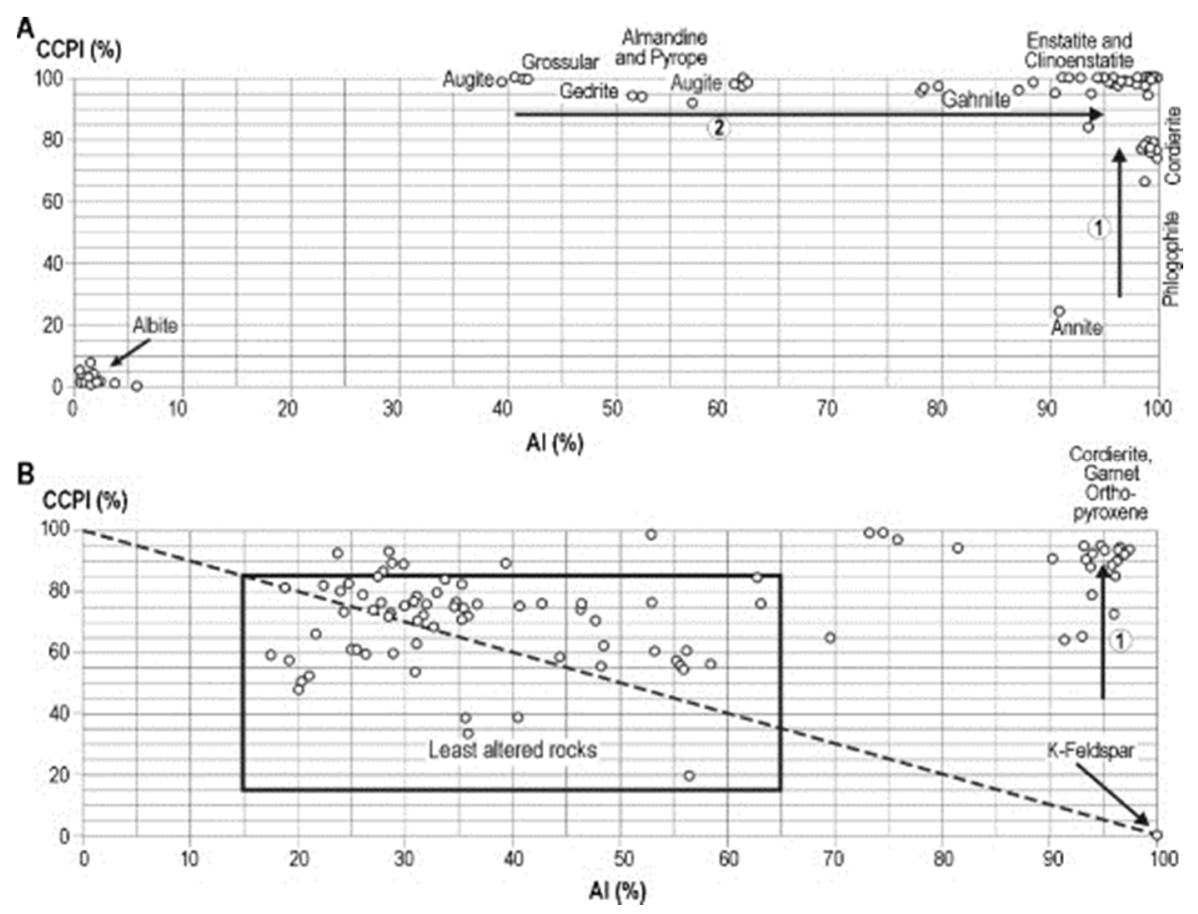

Fig. 6. Box plot diagrams of CCPI against AI for minerals (A) and whole rock compositions (B) from Kantienpan (CCPI and AI as defined in Fig. 5). The mineral composition trends shown as numbers 1 and 2 in these figures are discussed in the text. The least altered box as defined by Large et al. (2001) is shown in (B).

The pyroxenes belonging to the second trend are represented by augite with intermediate AI values, plotting to the left, and enstatite and clinoenstatite with high AI values that plot close to (Mg-rich) cordierite. Amphiboles of this trend include, hornblende with lower AI values (high $\mathrm{Ca}$ content), and cummingtonite and gedrite with higher AI values (high Mg contents). Two groups of garnets are present in these rocks, grossular with a low AI value (Ca-rich and low in $\mathrm{Mg}$ ), which plots to the left, and almandine and pyrope with high AI values (low in $\mathrm{Ca}$ and $\mathrm{Mg}$ rich) plotting to the right (Fig. 5 and Fig. 6).

\section{Whole rock compositions and the box plot}

The AI of rocks least affected by hydrothermal alteration range between 10 and 65 and the CCPI, between 15 and 85 (Large et al., 2001) (Fig. 5 and Fig. 6). It is assumed that the metamorphic equivalents of these rocks should plot in the same field. Rocks originally affected by diagenetic alteration, have an AI of $<57$ and plot below the epidote-K-feldspar join (Fig. 5 and Fig. 6).

The AI and CCPI values from drill holes KN11 and KN12 (Ghavami-Riabi, 2007) at the Kantienpan deposit fall into two areas in the box plot (Fig. 6B), namely that of rocks least affected by hydrothermal alteration and of rocks affected by hydrothermal alteration with AI values $>67$, and CCPI values $>60$. 
The box plot of samples from drill hole AP5 (Areachap), supplemented with samples of drill hole AP2 are shown in Fig. 5A. These samples may be separated into three areas in the diagram, namely:

(a) least altered samples;

(b) altered samples with $\mathrm{AI}>70$ and $\mathrm{CCPI}>70$;

(c) samples plotting outside the least altered field of Large et al. (2001).

The latter group of samples is from rocks that could have had chemical sedimentary precursors (similar to the Kuroko cap rocks), because they are enriched in quartz, carbonate and sulphate minerals (calcite, dolomite, barite, anhydrite) and are directly related to the sulfide ore zone, but since they are not believed to have formed during the primary alteration process itself, they will not be further considered here.

Stratigraphic variation in the AI and CCPI values at Areachap is demonstrated in Fig. 7 (drill hole AP5). The figure clearly shows that the highest AI (>65) and CCPI $(>75)$ values correspond to the footwall alteration zone in the overturned sequence. Similarly Fig. 8 shows that the alteration zone below the ore zone at Kantienpan has the highest AI and CCPI values.

\section{Quantification of the degree of alteration of the precursor rocks}

The degree of alteration undergone by the precursor rocks at the time of ore formation may be quantified using the isocon method, as proposed by Grant (1986), by comparing the rocks in the alteration zone with the least altered precursor rock. This method identifies those elements that remained in the rock during the alteration process (immobile) and those that were depleted or added (mobile). $\mathrm{Zr}$ is used here as an immobile element (Jenner, 1996). Elements plotting close to the line through the origin and $\mathrm{Zr}$ (the isocon line) are also considered to have behaved immobile during the primary alteration and are listed below. The change in concentration of an investigated element is calculated relative to the isocon line and represented by the delta $(\Delta)$ value.

An isocon diagram comparing the least altered biotite-gneiss, $C_{\mathrm{o}}$ (sample AP5/35, and altered biotite-gneiss, $C_{\mathrm{a}}$ (AP5/32), in the succession at Areachap is shown in Fig. 9. The calculated $\Delta$ values for oxides and trace elements for drill hole AP5 in the Areachap area are given in Table 1. As in most VMS deposits, the intensity of alteration is variable. To illustrate that, Table 1 lists both the minimum and maximum $\Delta$ values calculated for all samples analysed. 

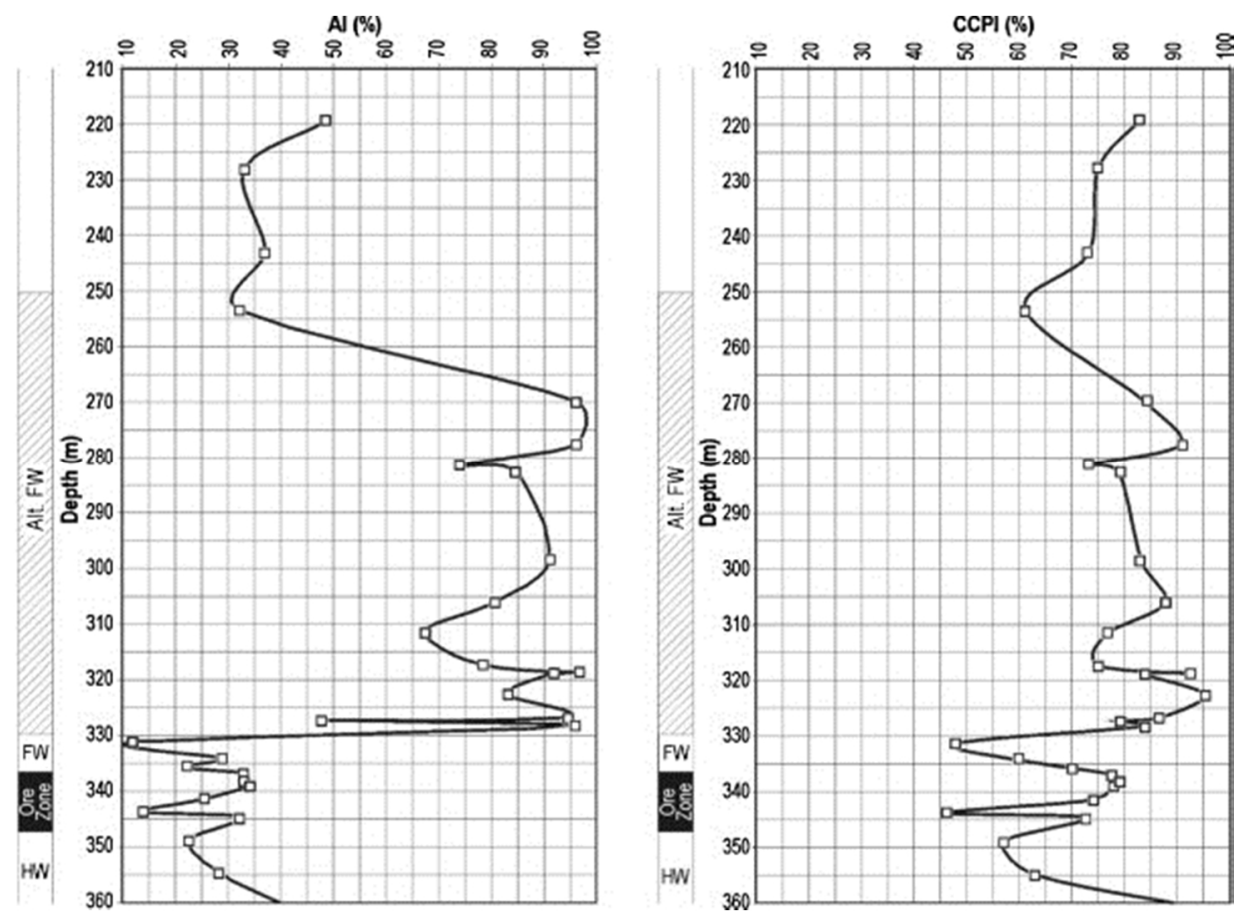

Fig. 7. The variation in the AI and CCPI values (as defined for Fig. 5) for the overturned stratigraphic sequence in drill hole AP5 at Areachap. Massive sulfide zone indicated in black and alteration zone hatched.
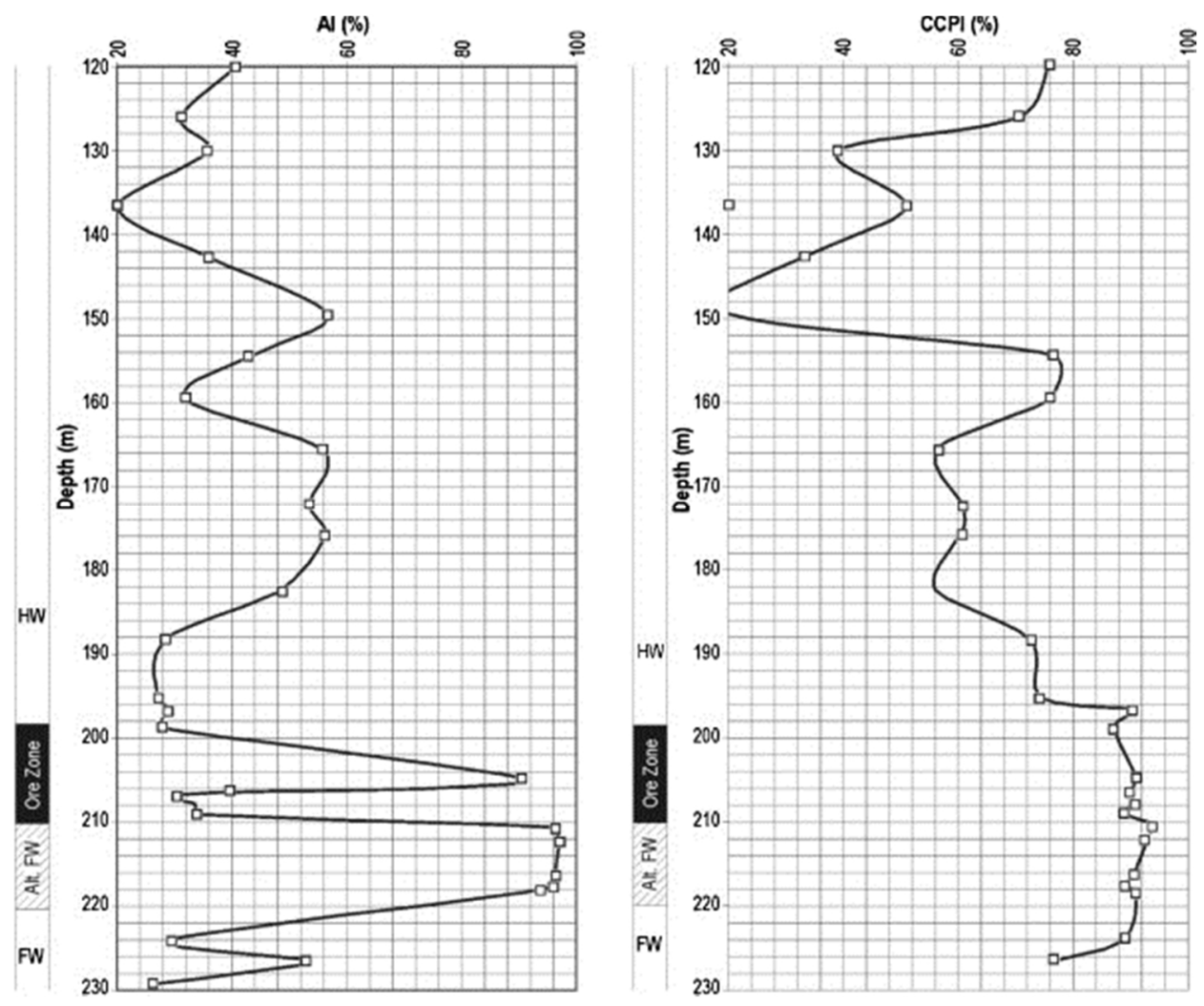

Fig. 8. The variation of AI and CCPI values from the succession in drill hole KN11 (Kantienpan). Massive sulfide zone indicated in black and alteration zone hatched. 


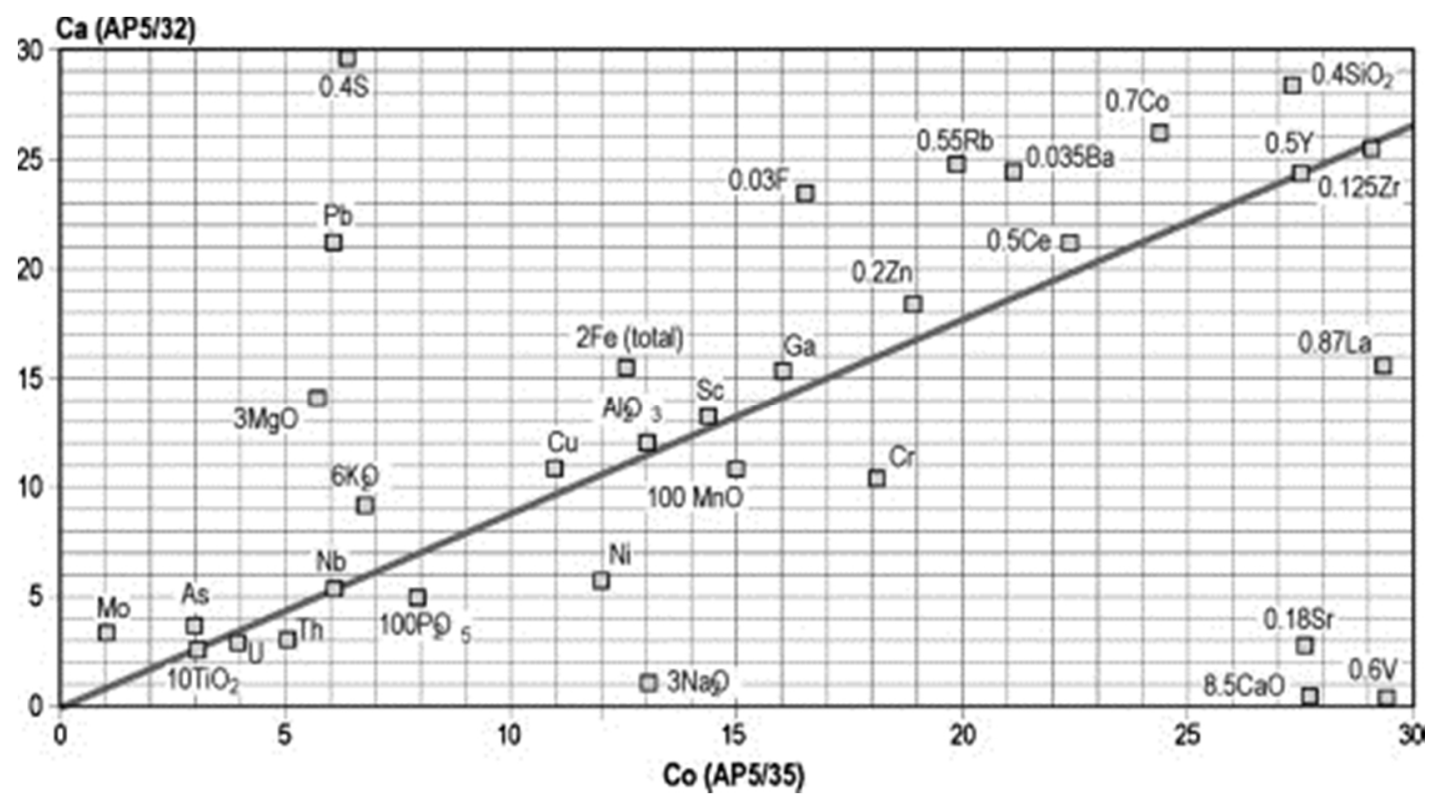

Fig. 9. An isocon diagram for samples AP5/35 (the least altered biotite-gneiss) and AP5/32 (altered biotite-gneiss) from drill hole AP5 in the Areachap area.

Table 1. Percentage of gains and losses in drill hole AP5 and $\Delta$ values for Areachap samples. Sample AP5/35 is assumed to be the unaltered precursor for altered samples AP5/23, 29, 30, and 32. Isocon line based on $\mathrm{Zr}$.

\begin{tabular}{|l|l|l|l|l|l||}
\hline $\begin{array}{c}\text { Elements and } \\
\text { oxides }\end{array}$ & $\begin{array}{c}\text { Minimum } \\
\Delta \text { Value }\end{array}$ & $\begin{array}{c}\text { Maximum } \\
\Delta \text { Value }\end{array}$ & $\begin{array}{c}\text { Composition } \\
\mathbf{A P 5} / 35\end{array}$ & $\begin{array}{l}\text { Gain or } \\
\text { loss (\%) }\end{array}$ & Gain/loss \\
\hline $\mathrm{CaO}$ & -2.82 & -2.03 & 3.26 & -62 to -87 & Loss \\
\hline \hline $\mathrm{Na}_{2} \mathrm{O}$ & -3.45 & -1.78 & 4.36 & -41 to -79 & Loss \\
\hline $\mathrm{K}_{2} \mathrm{O}$ & 0.56 & 0.61 & 1.13 & $50-54$ & Gain \\
\hline $\mathrm{MgO}$ & 1.42 & 3.03 & 1.92 & $74-158$ & Gain \\
\hline \hline $\mathrm{FeO}$ & 0.44 & 8.28 & 6.28 & $7-132.2$ & Gain \\
\hline \hline $\mathrm{SiO}_{2}$ & 10.15 & 33.98 & 68.26 & $15-50$ & Gain \\
\hline \hline $\mathrm{Al}_{2} \mathrm{O}_{3}$ & -0.06 & 1.12 & 13.05 & -0.5 to 9 & $\begin{array}{l}\text { Gain and } \\
\text { loss }\end{array}$ \\
\hline \hline $\mathrm{TiO}_{2}$ & -0.03 & 0.04 & 0.31 & -10 to 13 & $\begin{array}{l}\text { Gain and } \\
\text { loss }\end{array}$ \\
\hline $\mathrm{MnO}$ & -0.05 & -0.02 & 0.15 & -13 to -33 & Loss \\
\hline \hline $\mathrm{P}_{2} \mathrm{O}_{5}$ & -0.03 & 0.00 & 0.08 & -38 to 0 & Loss \\
\hline \hline $\mathrm{Ga}$ & -0.82 & 5.19 & 16 & -5 to 32 & $\begin{array}{l}\text { Gain and } \\
\text { loss }\end{array}$ \\
\hline \hline $\mathrm{Rb}$ & 0.69 & 19.59 & 36 & $2-54$ & Gain \\
\hline \hline $\mathrm{Sr}$ & -119.80 & -69.13 & 153 & -45 to -78 & Loss \\
\hline
\end{tabular}




\begin{tabular}{|c|c|c|c|c|c|}
\hline $\begin{array}{c}\text { Elements and } \\
\text { oxides }\end{array}$ & $\begin{array}{c}\text { Minimum } \\
\Delta \text { Value } \\
\end{array}$ & \begin{tabular}{|c|} 
Maximum \\
$\Delta$ Value \\
\end{tabular} & $\begin{array}{c}\text { Composition } \\
\text { AP5/35 } \\
\end{array}$ & $\begin{array}{r}\text { Gain or } \\
\text { loss (\%) }\end{array}$ & Gain/loss \\
\hline As & 0.48 & 2.05 & 3 & $16-68$ & Gain \\
\hline $\mathrm{Ba}$ & 177.47 & 966.44 & 604 & $29-160$ & Gain \\
\hline $\mathrm{Cu}$ & -5.06 & 128.28 & 11 & \begin{tabular}{|l|}
-46 to \\
1173 \\
\end{tabular} & $\begin{array}{l}\text { Gain and } \\
\text { loss } \\
\end{array}$ \\
\hline $\mathrm{Pb}$ & -2.04 & 17.54 & 6 & -34 to 292 & \begin{tabular}{|l|} 
Gain and \\
loss
\end{tabular} \\
\hline $\mathrm{S}$ & 5.67 & 27633.37 & 16 & $35-172709$ & Gain \\
\hline $\mathrm{Zn}$ & -41.21 & 24.55 & 95 & -44 to 26 & $\begin{array}{l}\text { Gain and } \\
\text { loss }\end{array}$ \\
\hline $\mathrm{Ce}$ & -12.09 & 11.75 & 45 & -27 to 26 & $\begin{array}{l}\text { Gain and } \\
\text { loss }\end{array}$ \\
\hline $\mathrm{Cr}$ & -5.57 & 3.85 & 18 & -31 to 21 & $\begin{array}{l}\text { Gain and } \\
\text { loss } \\
\end{array}$ \\
\hline Co & 7.20 & 20.57 & 35 & $21-59$ & Gain \\
\hline $\mathrm{Ni}$ & -7.08 & 1.19 & 12 & -59 to 10 & \begin{tabular}{|l} 
Gain and \\
loss \\
\end{tabular} \\
\hline Sc & 0.46 & 2.51 & 14 & $3-17$ & Gain \\
\hline $\mathrm{F}$ & 272.25 & 1152.13 & 551 & $49-209$ & Gain \\
\hline $\mathrm{Nb}$ & -0.70 & 0.02 & 6 & -11 to 1 & $\begin{array}{l}\text { Gain and } \\
\text { loss }\end{array}$ \\
\hline $\mathrm{La}$ & -14.39 & -3.98 & 34 & -43 to -12 & Loss \\
\hline Th & -1.44 & 0.45 & 5 & -28 to 9 & \begin{tabular}{|l|} 
Gain and \\
loss
\end{tabular} \\
\hline $\mathrm{V}$ & -42.17 & -31.08 & 49 & -86 to -63 & Loss \\
\hline $\mathrm{U}$ & -0.38 & 0.50 & 4 & -10 to 13 & \begin{tabular}{|l} 
Gain and \\
loss
\end{tabular} \\
\hline$Y$ & 0.78 & 16.93 & 55 & $1-31$ & Gain \\
\hline
\end{tabular}

The isocon diagram comparing the least altered biotite-gneiss and altered biotite-gneiss from the alteration zone identified in drill hole KN11, in the Kantienpan area, is shown in Fig. 10. The calculated $\Delta$ values are given in Table 2. Sample KN11/44 is used as representative of the precursor composition. These conclusions confirm the geological and petrographic interpretation regarding the presence of hydrothermal alteration zones directly related to the one side of the deformed and metamorphosed ore deposits, as identified by a distinct metamorphic mineral assemblage in a lithological zone, for which the precursor is unlikely to have been anything different than an alteration pipe. The elements involved in the process and identified either as 
immobile or mobile confirms the VMS model and the similarity between the Copperton Group of massive sulfide deposits (Theart et al., 1989).

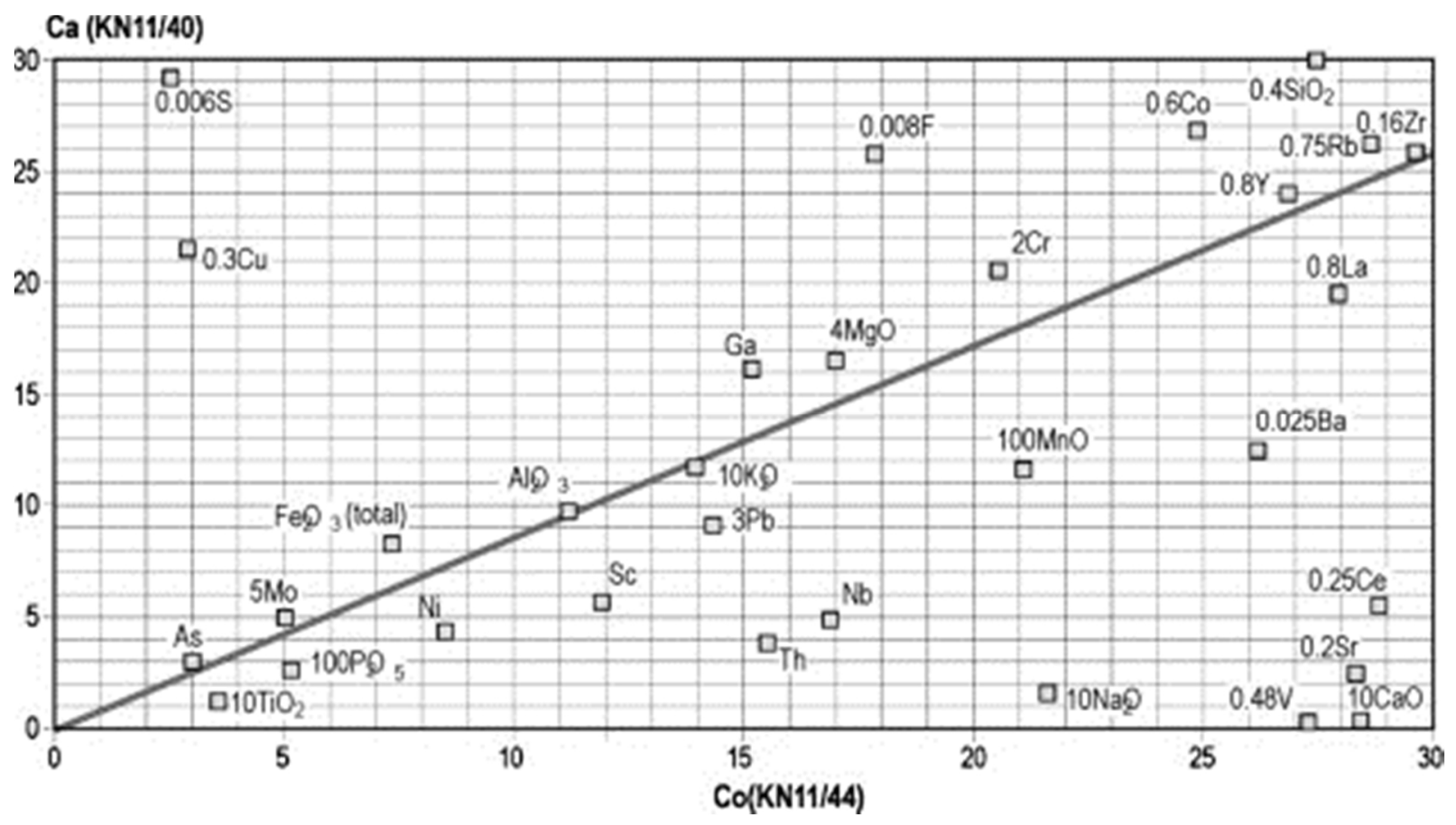

Fig. 10. An isocon diagram for samples KN11/44 (the least altered biotite-gneiss) and KN11/40 (altered biotitegneiss) from drill hole KN11 in the Kantienpan area.

Table 2. Percentages of gains and losses in drill hole KN1 land $\Delta$ values for Kantienpan samples. Sample $\mathrm{KN} 11 / 44$ is considered to be the unaltered precursor for altered sample KN11/40. Isocon line based on $\mathrm{Zr}$.

\begin{tabular}{|c|c|c|c|c|}
\hline Elements and oxides & $\Delta$ Value & Composition KN11/44 & Gain or loss (\%) & Gain/loss \\
\hline $\mathrm{CaO}$ & -2.43 & 2.84 & -85.6 & Loss \\
\hline $\mathrm{Na}_{2} \mathrm{O}$ & -1.72 & 2.16 & -79.6 & Loss \\
\hline $\mathrm{K}_{2} \mathrm{O}$ & -0.05 & 1.39 & -3.6 & Loss \\
\hline $\mathrm{MgO}$ & 0.41 & 4.25 & 9.6 & Gain \\
\hline $\mathrm{FeO}$ & 1.87 & 7.34 & 25.5 & Gain \\
\hline $\mathrm{SiO}_{2}$ & 15.47 & 68.55 & 22.6 & Gain \\
\hline $\mathrm{Al}_{2} \mathrm{O}_{3}$ & -0.07 & 11.19 & -1 & Loss \\
\hline $\mathrm{TiO}_{2}$ & -0.19 & 0.36 & -53 & Loss \\
\hline $\mathrm{MnO}$ & -0.07 & 0.21 & -33 & Loss \\
\hline $\mathrm{P}_{2} \mathrm{O}_{5}$ & -0.02 & 0.05 & -40 & Loss \\
\hline $\mathrm{Ga}$ & 2.99 & 15 & 20 & Gain \\
\hline $\mathrm{Rb}$ & 1.71 & 38 & 5 & Gain \\
\hline $\mathrm{Sr}$ & $\mid-110.60$ & 142 & -78.1 & Loss \\
\hline
\end{tabular}




\begin{tabular}{|l|l|l|l|l|}
\hline Elements and oxides & \multicolumn{1}{|l|}{ V Value } & Composition KN11/44 & Gain or loss (\%) & Gain/loss \\
\hline $\mathrm{As}$ & 0.39 & 3 & 13 & Gain \\
\hline $\mathrm{Ba}$ & -417.36 & 1048 & -40 & Loss \\
\hline \hline $\mathrm{Cu}$ & 62.95 & 10 & 648 & Gain \\
\hline $\mathrm{Pb}$ & -1.15 & 5 & -24 & Loss \\
\hline \hline $\mathrm{S}$ & 447.60 & 430 & 104 & Gain \\
\hline \hline $\mathrm{Zn}$ & 154.86 & 125 & 124 & Gain \\
\hline $\mathrm{Ce}$ & -78.24 & 116 & -68 & Loss \\
\hline $\mathrm{Cr}$ & 1.33 & 10 & 13 & Gain \\
\hline $\mathrm{Co}$ & 8.52 & 42 & 21 & Gain \\
\hline $\mathrm{Ni}$ & -3.20 & 9 & -38 & Loss \\
\hline $\mathrm{Sc}$ & -4.87 & 12 & -41 & Loss \\
\hline \hline $\mathrm{F}$ & 1270.73 & 2228 & 57 & Gain \\
\hline \hline $\mathrm{Nb}$ & -9.90 & 17 & -59 & Loss \\
\hline $\mathrm{La}$ & -6.01 & 35 & -17 & Loss \\
\hline $\mathrm{Th}$ & -10.02 & 16 & -65 & Loss \\
\hline \hline $\mathrm{V}$ & -48.67 & 57 & -86 & Loss \\
\hline $\mathrm{U}$ & 0.39 & 3 & 13 & Gain \\
\hline $\mathrm{Y}$ & 0.79 & 34 & 2 & Gain \\
\hline \hline
\end{tabular}

In general, the alteration zones at Areachap and Kantienpan are enriched in $\mathrm{MgO}, \mathrm{Fe}_{2} \mathrm{O}_{3 \text { (total) }}, \mathrm{S}$, $\mathrm{Zn}, \mathrm{SiO}_{2}$, and $\mathrm{Co}$ and depleted in $\mathrm{Na}_{2} \mathrm{O}, \mathrm{CaO}, \mathrm{Sr}, \mathrm{Ni}, \mathrm{V}$ and $\mathrm{La}$. $\mathrm{Ba}$ is enriched in the footwall alteration zone at Areachap, but depleted at the Kantienpan deposit. Elements and oxides that behaved relatively immobile include $\mathrm{Zr}, \mathrm{TiO}_{2}, \mathrm{P}_{2} \mathrm{O}_{5}, \mathrm{MnO}, \mathrm{Al}_{2} \mathrm{O}_{3}, \mathrm{Y}$, and $\mathrm{U}$. Theart et al. (1989) reported that the alteration zone at the Prieska $\mathrm{Cu}-\mathrm{Zn}$ Mine is enriched in $\mathrm{MgO}, \mathrm{K}_{2} \mathrm{O}, \mathrm{V}, \mathrm{Sc}, \mathrm{Ni}$, $\mathrm{Ba}, \mathrm{Cu}$ and $\mathrm{Zn}$, and depleted in $\mathrm{CaO}, \mathrm{Na}_{2} \mathrm{O}, \mathrm{Sr}$ and $\mathrm{SiO}_{2}$.

\section{Summary and conclusions}

The metamorphic minerals that characterize the alteration zones at the Areachap and Kantienpan VMS deposits include plagioclase, almandine and pyrope, enstatite and clinoenstatite, cummingtonite and gedrite, cordierite and sillimanite. Some of these minerals display characteristic chemical variations relative to their respective positions in the alteration system, such as:

(a) Plagioclase is more Ca-rich close to the ore zone and more Na-rich further away from the ore zone at Kantienpan.

(b) Pyroxene adjacent to the ore zone in $\mathrm{KN} 11$ has the highest relative $\mathrm{Mg}^{*}$ value (the ratio: $\left.100 \mathrm{Mg} /\left(\mathrm{Mg}+\mathrm{Fe}^{2+}+\mathrm{Fe}^{3+}+\mathrm{Mn}\right)\right)$ and this value decreases in the stringer zone and hangingwall. 
The $\mathrm{Mn}$ and $\mathrm{Fe}$ content of pyroxene near the ore zone and alteration zones are lower than those in pyroxene further away from these zones.

(c) Cordierite has the highest $\mathrm{Mg} \#$ in the ore zone and this decreases away from the ore zone. The Mn content of cordierite in the ore zone is higher than in the footwall alteration zone.

(d) The almandine and pyrope components calculated for garnet are high in the alteration zones, whereas the spessartine and grossular components are low. Garnet in the ore zone has high $\mathrm{Ca}$ contents but low $\mathrm{Mg}$ contents.

(e) Based on the $\mathrm{Mg}$ and Fe values in mica, the Mg-rich variety, phlogopite is more common adjacent to the ore zone.

(f) The peraluminous nature of the alteration zone is reflected by the presence of spinel (gahnite type close to the ore zone).

Isocon studies have shown that the alteration zones at the Areachap and Kantienpan deposits are enriched in $\mathrm{MgO}, \mathrm{Fe}_{2} \mathrm{O}_{3 \text { (total) }}, \mathrm{S}, \mathrm{Zn}, \mathrm{SiO}_{2}$, and $\mathrm{Co}$, and depleted in $\mathrm{Na}_{2} \mathrm{O}, \mathrm{CaO}, \mathrm{Sr}, \mathrm{Ni}, \mathrm{V}$ and $\mathrm{La}$. $\mathrm{Ba}$ is enriched in the footwall alteration zone at the Areachap deposit, but depleted at the Kantienpan deposit. Elements and oxides that were relatively immobile include $\mathrm{Zr}, \mathrm{TiO}_{2}, \mathrm{P}_{2} \mathrm{O}_{5}$, $\mathrm{MnO}, \mathrm{Al}_{2} \mathrm{O}_{3}, \mathrm{Y}$, and $\mathrm{U}$.

The lithogeochemical methods used here effectively identified and characterized the footwall alteration zones of VMS deposits in upper amphibolite to granulite-grade metamorphic rocks. These lithogeochemical and mineralogical characteristics may now be used in exploration in this and similar terrains to identify concealed VMS mineralization. The box plot suggested by Large et al. (2001) and modified for metamorphic rocks here, is shown to be a potential method in discriminating between those rocks of which the precursors underwent hydrothermal alteration, from those that were unaffected by this process. It furthermore may assist in identifying rock forming minerals of which the mineral compositions could be used as proximity indicators to VMS mineralization. In the box plot, rocks displaying the highest AI and CCPI values (CCPI $>70$ and $\mathrm{AI}>70$ ) could be identified as those of which the precursors were affected by hydrothermal alteration processes at the time of ore formation, in a footwall alteration zone of a VMS deposit.

\section{Acknowledgements}

The research was partly funded by CERMOD at the University of Pretoria. Kumba Resources Ltd and Mr. D. Rossouw are thanked for a field visit in September 2003 and access to drill core for sampling. We are grateful to several members of the Geology Department of the University of Pretoria for their assistance during the course of this research. Messrs. M. Claassen and P. Sibiya are thanked for making of the thin sections, Mrs M. Loubser for XRF analyses and Ms. I. Chimeloan for drafting some of the geological maps. 


\section{References}

Barrett, T.J., MacLean, W.H., Areback, H., 2005. The Palaeoproterozoic Kristinberg VMS deposit, Skelleffte district, Northern Sweden; Part II. Chemostratigraphy and alteration. Miner. Deposita 40, 368-395.

Barton, E.S., Burger, A.J., 1983. Reconnaissance isotopic investigation of the marginal zoneoftheProterozicNamaquamobile belt. In:UpingtonGeotraverse.Geol.Soc. S. Afr (Special Publication 10), pp. 173-192.

Bennett, H., Oliver, G., 1992. XRF Analysis of Ceramics, Minerals and Applied Materials. John Wiley and Sons, pp. 67-93.

Bernier, L.R., MacLean, W.H., 1993. Lithogeochemistry of a metamorphosed VMS alteration zone at Montauban, Grenville Province, Quebec. Explor. Min. Geol. 2, 367-386.

Bernier, L.R., Pouliot, G., MacLean, W.H., 1987. Geology and metamorphism of the Montauban north gold zone; ametamorphosed polymetallic exhalative deposit, Grenville Province, Quebec. Econ. Geol. 82, $2076-2090$.

Catuneanu, O., Wopfner, H., Eriksson, P.G., Cairncross, B., Rubidge, B.S., Smith, R.M.H., Hancox, P.J., 2005. The Karoo basins of south-central Africa. J. Äfr. Earth Sci. 43, $211-253$.

Cornell, D.H., Kroner, A., Humphreys, H.C., Griffin, G., 1990a. Age of origin of the polymetamorphosed Copperton Formation, Namaqua-Natal Province, by single grain zircon Pb-Pb dating. S. Afr. J. Geol. 93, 709714

Cornell, D.H., Theart, H.F.J., Humphreys, H.C., 1990b. Dating a collision-related meta-morphic cycle at Prieska copper mines, South Africa. In: Spry, P.G., Bryndzia, T. (Eds.), Regional Metamorphism of Ore Deposits and Genetic Implications, vol. 11. VSP, Utrecht, pp. 97-116.

Cornell, D.H., Humphreys, H.C., Theart, H.F.J., Scheepers, D.J., 1992.Acollision-related pressure-temperature-time path for Prieska copper mine, Namaqua-Natal tectonic Province: South Africa. Precambrian Rev. 59, 43-71.

Galley, A.G., Bailes, A.H., Kitzler, G., 1993. Geological setting and hydrothermal evolution of the Chisel Lake and North Chisel $\mathrm{Zn}-\mathrm{Pb}-\mathrm{Cu}-\mathrm{Ag}-\mathrm{Au}$ massive sulphide deposits, Snow Lake, Manitoba. Explo. Min. Geol. 2, 271295.

Geringer, G.J., Botha, B.J.V., Pretorius, J.J., Ludick, D.J., 1986. Calc-alkaine volcanism along the eastern margin of the Namaqua mobile belt, South Africa - a possible middle proterozoic volcanic arc. Precambrian Res. 33, $139-170$.

Geringer, G.J., Humphreys, H.C., Scheepers, D.J., 1994. Lithostratigraphy, protolithol-ogy, and tectonic setting of the Areachap group along the eastern margin of the Namaqua mobile belt, South Africa. S. Afr. J. Geol. 97, 78100.

Geringer, G.J., Ludick, D.J., 1990. Middle-Proterozoic calc-alkaline shoshonitic volcanism along the eastern margin of the Namaqua mobile belt, South Africa-implications for tectonic evolution in the area. S. Afr. J. Geol. 93, 389-399.

Ghavami-Riabi, R., 2007. Geochemical exploration for base metal sulfide deposits in an arid environment (eastern Namaqua Province), South Africa. Unpublished Ph.D. dissertation, University of Pretoria.

Ghavami-Riabi, R., Theart, H.F.J., De Jager, C., 2008. Detection of concealed Cu-Zn massive sulfide mineralization below eolian sand and a calcrete cover in the eastern part of the Namaqua Metamorphic Province, South Africa. J. Geochem. Explor. 97, 83-101.

Gorton, R.K., 1981. The petrology of the Kielder sulfide bodies and their wall rocks. District of Prieska, N. Cape, South Africa. Unpublished M.Sc. dissertation, University Cape Town, $153 \mathrm{pp}$.

Grant, J.A., 1986. The isocon diagram - a simple solution to Gresens' equation for metasomatic alteration. Econ. Geol. 81, 1976-1982.

Gresens, R.L., 1967. Composition-volume relationships of metasomatism. Chem. Geol. 2, 47-55.

Hartnady, C.J.H., Joubert, P., Stowe, C.W., 1985. Proterozoic crustal evolution in southwestern Africa. Episodes 8, 36-44.

Humphreys, H.C:, 1993. Metamorpic evolution of amphibole-bearing aluminous gneisses from the Eastern Namaqua Province, South Africa. Am. Mineral. 78, 1041-1055.

Humphreys, H.C., Van Bever Donker, J.M., Scott, W.D., Van Schalkwyk, L., 1988. The early deformational history of the eastern Namaqua Province: new evidence from Prieska copper mines. S. Afr. J. Geol. 91, $174-183$. 
Ishikawa, Y., Sawaguchi, T., Iwaya, S., Horiuchi, M., 1976. Delineation of prospecting targets for Kuroko deposits based on modes of volcanism of underlying dacite and alteration halos. Min. Geol. 26, 105-117 (in Japanese with English abstract).

Jenner, G.A., 1996. Trace element geochemistry of igneous rocks: geochemical nomenclature andanalyticalgeochemistry.In:Wyman, D.A.(Ed.), TraceElement Geochemistry of Volcanic Rocks: Applications for Massive Sulfide Exploration, vol. 12. Geological Association of Canada, pp. 51-77 (Short course notes).

Large, R.R., Gemmell, J.B., Paulick, H., Huston, D.L., 2001. The alteration box plot: a simple approach to understanding the relationship between alteration mineralogy and lithogeochemistry associated with volcanichosted massive sulfide deposits. Econ. Geol. 96, 957-971.

Middleton, R.C., 1976. The geologyof the Prieska copper mines (Pty) Ltd. Econ. Geol. 71, 328-350.

Moen, H.F.G., 1988. 2820 Upington 1:250000 Geological Series. Council for Geo-science, Pretoria, South Africa.

Moore, J.M., Watkeys, M.K., Reid, D.L., 1990. The regional setting of the Aggeneys/Gamsberg base metal deposits Namaqualand, South Africa. In: Spry, P.G., Bryndzia, L.T. (Eds.), Regional Metamorphism of Ore Deposits and Genetic Implications: Proceedings of the 28th International Geological Congress. Washington, USA, VSP, Utrecht, Netherlands, pp. 77-95.

Pupin, J.P., 1980. Zircon and granite petrology: contributions to mineral. Petrology 73, 207-220.

Rossouw, D., 2003. A technical risk evaluation of the Kantienpan volcanic-hosted massive sulfide deposit and its financial viability. Unpublished M.Sc., Dissertation, University of Pretoria, $118 \mathrm{pp}$.

Ryan, P.J., Lawrence, R.D., Lipson, R.D., Moore, J.M., Paterson, A., Stedman, D.P., Van Zyl, D., 1986. In: Anhaeusser, C.R., Maske, S. (Eds.), The Aggeneys Base Metal Sulfide Deposits, Namaqualand District, Mineral Deposits of Southern Africa, II. Geol. Soc. S. Afr., Johannesburg, pp. 1447-1473.

Schade, J., Cornell, D.H., Theart, H.F.J., 1989. Rare earth element and isotopic evidence for the genesis of the Prieska massive sulfide deposit, South Africa. Econ. Geol. 84, 49-63.

Stowe, C.W., 1983. The Upington geotraverse and its implications for craton margin tectonics. In: Botha, B.J.V. (Ed.), Namaqualand Metamorphic Complex. Geol. Soc. S. Afr., pp. 147-171 (Special Publication 10).

Theart, H.F.J., 1985. Copperton-Areachap $\mathrm{Cu}-\mathrm{Zn}$ mineralization. Unpublished Ph.D. Dissertation, University Stellenbosch, 329 pp.

Theart, H.F.J., Cornell, D.H., Schade, J., 1989. Geochemistry and metamorphism of the Prieska Zn-Cu deposit, South Africa. Econ. Geol. 84, 34-49.

Thomas, R.J.. Cornell, D.H., Moore, M.J., Jacobs, J., 1994. Crustal evolution of the Namaqua-Natal metamorphic Province, Southern Africa. S. Afr. J.Geol. 97, 8-14.

Voet, H.W., King, B.H., 1986. The Areachap copper-zinc deposit, Gordonia district. In: Maske, S. (Ed.), Mineral Deposits of Southern Africa, vol. 2. Geol. Soc. S. Afr., pp. 1529-1539.

Watson, J.S., 1996. Fast, simple method of powder pellet preparation for X-ray fluorescence analysis. X-ray Spectrom. 25, 173-174.

Zaleski, E., Froese, E., Gordon, T.M., 1991. Metamorphic petrology of Fe-Zn-Mg-Al alterationatthe Limda volcanogenicmassive sulphide deposit, Snow Lake, Manitoba. Can. Mineral. 29, 995-1017. 